\title{
VII. Reflections on some mineralogical systems. Translated entire from the French, with notes by the translator
}

\author{
R. Chenevix Esq. F.R.S. M.R.I.A.
}

To cite this article: R. Chenevix Esq. F.R.S. M.R.I.A. (1811) VII. Reflections on some mineralogical systems. Translated entire from the French, with notes by the translator , Philosophical Magazine Series 1, 37:153, 39-51, DOI: 10.1080/14786441108563236

To link to this article: http://dx.doi.org/10.1080/14786441108563236

曲 Published online: 18 May 2009.

Submit your article to this journal $\pi$

Џll Article views: 2

Q View related articles ¿ 
are surrounded by perpendicular rocks, that sink in that direction to an almost unfathomable depth in the sea. Besides, how can we account for that similarity of manners, customs, colour, and even language, among the inhabitants of islands so distant, that no mode of navigation they practise could ever make them acquainted, or to have any communication with one another? If these islands were thrown up from the bottom of the sta, their inhabitants would not be thrown up along with them, and all with the same customs and language. Now if this immense part of the globe was a continent before the deluge, the inhabitants might be alike; and if the elevated parts were above the waters, (a circumstance more than probable, inhabitants might be saved upon them, with every circumstance of similarity we now find anong them; for that revolution is not of so remote a date, but remains of antediluvian mamers might exist at this time."

VII. Reflections on some. Mineralogical Systems. By R. Chenevix, Esq. F.R.S. and M.R.I.A., हீc. Translated entire from the French, with Notes by the Translator.

[Continued from vol.xxxvi.p. 361.]

\section{GERMAN SYSTEM OF NOMENCLATURE.}

$\mathrm{I}_{\mathrm{r}}$ T would become fastidious and almost useless to divell longer on the external characters of Werner. We can conceive the details into which this philosopher has entered; but to convey an idea of the minutiæ with which the Germans think it necessary to treat a subject, I shall give the shortest extract possible from 28 pages, in which Emmerling speaks of nomenclature. I intend this specimen as a historical and characteristic fragment; but I anticipate that the reader will dread the tediousness of following me, although I propose to favour him with a great part of the original.

I. Object of the nomenclature (zweck der fossilien benennungen).--It is necessary in every art or science to have words or names to designate the things of which we treat. They serve particularly to fix the different concrete ideas, to express ourselves intelligibly, and to communicate our thoughts.

II. Different sorts of names (verschiedene arten dersel$\boldsymbol{b} \epsilon n)$.- Of these there are two; trivial, and systematic.

A. (Triviallen benennungen). The trivial names are those ${ }_{4}$ which. 
which minerals receive in common life, and often from miners. Every language possesses them, and some of them have even passed to others; as quartz, blende, \&c.

The trivial names may be divided into two: general and particular trivial names.

1. The general trivial names (algemeine triviallen benennungen) are those commonly used in any language and received into another. They are importani, inasmuch as they are used by philosophers themselves, who have divided them into two.

a. General trivial names (haupt trivialnamen) are those most generally known and used.

b. Accidental general trivial names (neben trivialnamen) are those least known; such as cat-gold or cat-silver (argent de chat) [lameliforme mica, Haüy], Muscovy glass, for mica, \&c.

2. The particular trivial names comprehend those used by cerlain classes of persons, and in certain countries. They are divided into three (besondre trivial;amen).

a. Provincial or local names (provenziellen und local benenizungen). The peasantry in certain provinces use these names; mispickel, in Saxony, for arsenical pyrites ; gelf, gelferz or gelft, is the Hungarian name of coppery pyrites. $b$. Officinal names (officinelle benemungen) are those used by apothecaries and other traders in the shops; as bloodstone, nephretic, \&c.

c. Technical names (iechnologische benennungen) are those used by artists or workmen. Statuaries call all kinds of stone which are easily wrought, marble.

$B$. Systematic names (systematische benennungen) are those used by philosophers; they should be characterized by precision and perspicuity.

III. Principles and rules for forming these names.

$A$. Rule for the formation of general trivial names.Werner gives eight rules for this purpose. The names ought to be distinct, definite or clear (unterscheidend); just, with respect to the thing (sachrichtig); correct, with respect to language (sprachrichtig); descriptive (bezeichnend); short (kurz); fixed and applied only to a single mineral (festgesetz); unique, (einzig); and distinct from one another (ausgeziechuet).

1. A name is distinct when it belonys only to a single species: spar, schiste, and schorl, are not distinct; but feldspar, fluor spar, argillaceous schiste, \&c., are.

2. It is just with respect to the thing, when it does not 
give a false idea of the mineral. Smoked topaz [quartz hyalin enfumé of Brogniart] transgresses in this point of view, since it is not a topaz.

3. Correct or accurate with respect to language, when, on being written or spoken, it is not inimical to the genius of the language. In this rule there are eight subdivisions.

$a$. When the name of a species is composed of a substantive and an adjective, the latter should be indeclinable. (Examples are cited in the German.)

l. When a name is composed of two words, that which gives the general idea should be first, and that which limits this idea, the last. (Examples of this rule are also given in German.)

$c$. When a name is composed of two, three, or four words, we should separate and unite them as the nature of the thing may require. Thus, grau-spies-glaserz, a mine of gray vitreous antimony.

$d$. All the names of species, whether simple or compound, should be written with an initial capital latter, as Grau-spies-glaserz. The varieties ought not to commence with a capital letter, but when their name differs from that of the species, as Amethyst, Prase. If there be an adjective to designate the variety, it ought to commence with a small letter ; thus, dichtes-Grau-spies-glaserz.

$e$. The names ought to be taken from one language only, as chrysolithe.

$f$. We ought not to translate names taken from other languages*. We should not say gold-stone instead of chrysolithe.

g. We should write and pronounce the words according to their true signification and etymology. The name of a species is rothgultigerz; it is improper to say, rothgulden, rothguldenerz, rothguldigeserz. (When a man is named Pierre (Peter), he ought not to be called James, nor even Pierrot).

$h$. In forming new names, it is necessary to consult analogy. Thus, sedative spar, phosphoric spar, are bad names, because the name of spar is properly applied to earthy sub. stances, and not to salts. (It has here been forgotten that

* This rule would be very proper if all the new names of minerals were de. rived frem the Greek, as has been done by Haüy; but if the Germans suppose that the French, Italians, Spanish and English should adopt their barbarous combinations of letters to designate minerals, they only betray their vanity at the expense of their common sense. This was too much even for Mr. Jameson; and his fate will perhaps be a warning to others, never again to attempt to sacrifice both classical and vernacular language on the altar of German gothicism.-Trans. 
the word is employed in the formation of the names calkspar, schiefferspar, braunspar, bitterspar, flutspar, scheverspar, wulfelspar, among the acidiferous substances; and only in the names demantspar, feldspar, and skhillespar, among the earthy minerals.)

4. Descriptive, in order to give an idea of the principal properties of minerals. There are six sources whence we should principally derive them, and four others which offer less advantage.

$a$. Some very remarkable external character. The word heavy spar, from its weight ; olivin, from its colour ; stinkstone [fetid carbonated lime of Haüy], from its odour, \&c.

$b$. Some physical or chemical property: as zeolite, in consequence of its effervescence by the action of fire; mine of magnetic iron, \&re.

c. Some constituent principle of the mineral : but the uncertainty of analyses militates a little against this source.

$d$. The usage of a mineral: as fire-stone [common flint, pyromacous silex, Linn. and Haüy], fullers' earth, porcelain earth, \&c.

$f$. Resemblance to certain other objects in the usage of common life: as pitch-stone, horn-stone, \&c.

The sources less proper for deriving names are comprehended in the history of the mineral. \&c.

$a$. Gcographical situation : as calcedony, Labrador stone,

$b$. Nature of the soil : as mine of marshes, mine of meadows (monasterx, wiesenerz).

c. The names of persons; but only when a philosopher has been the first to make known a mineral, its properties and uses : as Prehnite, Witherite, \&c*.

$d$. Some trait in the history of a mineral: as appatite.

5. Short, as long names are difficult to pronounce and inconvenient to write and to remember. Two words at most should be employed. (The Germans have forgotten this rule in their language and in their names. Dichtesgrau-speis-glas-erz, is composed of five words.) Dense-

* With this proviso it seems difficult to determine who may claim the right to the honour of transferring his name to a mineral, and also whether his Christian or family name or title should be preferred. Should the discoverer not happen to be an auther or professor, it appears that he has no right to the honour; and if he carry the mineral to Werner or any of his disciples, then it may lawfully be baptized with the name of the professor of Freyberg, or any of his followers who are called learned. The folly and vulgarity of such a system of nomenclature must be sufficiently evident; and were any proof wanting of its total inadequacy, the very example cited will furnish it, as every English reader must naturally ascribe the name Witherite rather to Dr. Withers than Withering.-Tesss. 
gris-antimoine-verre-mine, or, in French, mine d'antimoine grise vitreuse en masse, mine of gray vitreous antimony in a mass.

6. Fixed and applied to only one mineral. Plombagine has designated carburetted iron and sulphuretted molybdena.

7. Unique or singular; each mineral should have only one name : but here there is a real chaos in mineralogy.

8. Distinct from all others, in order to avoid confusion.

The question now is to know in what case we should introduce a new name.

1. When a new mineral is discovered.

2. When chemical analyses change the place of a mineral.

3. When a name transgresses the rules of a language or of analogy.

4. When a name is in contradiction with the known properties of a mineral.

5. When a name is applied to several minerals.

$B$. Rules for forming systematic names.

1. They should be taken from the learned languages.

2. They ought to be taken from among the principal trivial names, and at the same time to mark the genus to which the fossil belongs.

3. The name of the genus must be placed first, that of the species should follow; as silex quartzum, silex quartzum amethystus. The trivial name may be placed in a parenthesis.

4. Names taken from the Greek and Latin, like other trivial names, should be retained and employed with a Latin termination: as zeolithus, serpentinus, creta.

5. Finally, in the formation of systematic names, we must observe the rules already given for the formation of trivial names.

Such a mode of teaching might suit the borders of the Ohio, but cannot now be admitted in Europe.

I have attended in Germany fourteen lectures in the form of prolegomena, and a course of mineralogy, of which the following is the quintessence: "Gentlemen, it was necessary for the study of mineralogy that the world was created, and that man was made."

In the same course it was affirmed that the town in which it was delivered was built in consequence of the mines which are found in its vicinity, and on no account that the mines were discovered in consequence of the contiguity of the town.

If we give a block of marble to Praxiteles, and another to a common man, Praxiteles would make of his an Apollo,

a Venus, 
a Venus, a Laocoon : under the chissel of another, nothing would result but sparks and powder.

One shonld expect that principles laid down so much at length might be rigorously followed. I have cursorily remarked some deviations : the following are some others.

In geognosis there is a rock called weisstein, white-stone. I have heard, in a public course, the lescription of this rock in these term: Das weisstein ist grau, "the white-stone is gray."

Such names as cubicite, octaedrite, ought not to be adopted but when a mineral is the only one which possesses the forms indicated by these words, or which possesses no others.

But, what is still worse, is to introduce contradictions and inaccuracies of this kind into a part of mineralogy, the determination of which belongs to more profound knowledge and more elevated faculties of the human mind; in that part, the merit of which, if it be not entirely owing to accuracy, at least cannot exist without it: I mean, that it is a much more serious fault to apply mathematical, and consequentiy rigorous, names, to designate a thing which is not what the name inplies. Wurfel zeolithe is an example of this: the word means, cubic zeolite*. Under this denomination two of Haüy's species (analcime and chabasie) are comprehended (Brochant, vol. i. p. 304). Analcime, indeed, is cubic; hut chabasie is a rhomboid, which differs from a cube $3^{\circ}, 30$. The most vulgar empiricism could not excuse such a fault. The joiner or mason who had not a more correct idea of a cube, would descrve to remain unemployed.

It was at Freyberg that, for the first time in my life, I heard of a square with oblique sides (geschobene quadrat); of an almost cube (fast wurfel), \&c.

A word which agrees perfectly with these principles, but which is itself extremely vicious, is oryctometry. It is said that the system of Haüy is properly oryctometry, or the art of measuring fossils. I maintain that this idea could not be suggested but by ignorance which misconceived the principles of the author, or by disingenuosness which sought to pervert them. Were nothing more to be done than measuring fossils, it would require neither the talents of a man of learning, the calculation of a geometer, the reasoning of

* On this mineral Mr. Jameson observes, "Haüy has formed of this sub. species two distinct species, but without sufficient reason." Yet he has not shown why the crystallographer's reason is insufficient, if he really knew it; nor even condescended to communicate any collateral próof, or miscellaneous knowledge, rending to support the practice of his master,-Trans. 
a logician, nor the extended views of a philosopher. The first surveyor, the first joiner, might be as able as M. Haüy. Doubtless, it is necessary to measure certain relations of the figures of crystals, and estimate the angles and the sides; but not to banish these results into a note, as a celebrated German professor desires, and contents himself with saying, that carbonated lime presents the figure of a rhomboid whose angles have such or such a measure. It is to form the text, the base of a work, to extract from these results superior consequences which influence the whole mineral kingdom, and distribute it in a natural and luminous order; it is to set out from the point where empiricism ceases to see, and to raise one's self to conclusions which the philosopher alone can seize. Oryctometry is the manual part of Haüy's system, that which the eyes perceive; the remainder is for the understanding. No one has ever said that astronomy is astrometry or uranometry, altbough the heavens and the stars are measured. The chemist boils his acids, roasts his minerals, and blows the bellows of his forge; the calculator covers the leaves of his paper with rough signs and letters without order; the poet cuts his pen and dips it into ink : this is what all eyes may observe. But woe to the folly which limits the sallics of genius which produced the lliad, or conceived the doctrine of infinitesimals, to these manipulations.

I have heard $M$. Haüy reproached for misemploying the name phosphated lime, in giving it to that which, in the system of Werner, forms two different species, appatite and asparagus-stone. The fault is his who made two species of the same mineral.

M. Haüy has effected a great reform in the nomenclature of minerals. He is justly of opinion, that significant names which recall some characteristic property of the mineral to be named, or some circumstance relative to its history, are the most advantageous. Others prefer insignificant names for simple substances, and require significant names for compounds, in order to give an idea of their nature. Thus, in chemistry, they would banish the words oxygen and hydrogen; but sulphuric acid and sulphat of lime, appear to them excellent. The species are simple bodies, the unitics of mineralogy, and consequentiy should have insignificant names*. M. Haüy has created nearly the half of the names

which

* It is diffcult to conceive any possible advantage which could accrue to science from arbitrary names; they were never imposed on any thing in nature, but from ignorance and necessity. It may, indeed, be questioned, whether any human being ever designated any one thing by an appellation 
which he uses in his system. He has been reproached with having derived them from the Greek, because to comprehend them it is necessary to have studied that language. But to those who know not Greek, these names will enter into the class of insignificant; that is to say, among those which many persons consider as the best.

\section{RESULT OF THE SENSUAL SYSTEM OF CHARACTERS-DIF- FERENCE BETWEEN EMPIRICISM AND SCIENCE.}

If we consider the mineralogical system of Werner with respect to these two questions, - Whence did it set out ? where is it gone?-the answers will be very different. It is true, that the state of mineralogy was very deplorable before him; and all that he found in ancient authors was so vague and ill-conceived, founded on ideas so erroneous, that it was more likely to lead him into errors than to guide him.

He has indeed followed the same path as they; but we may say, that if they have travelled it before him, if they have indicated it to him, they have furnished him with very few of the means of rendering it practicable; and he has all the merit of setting out from a very remote point, to take new steps in aid of his own labour.

But has he arrived as far as he might have done, had he profited by every thing which surrounded him? This is what I capnot absolutely concede to him. Besides the ob-

which had no analogy, no real or imaginary relation, to something previously known, and that he studied to find an articulate sound for which he felt no predilection, no choice, nor reason. When we consider the universal and ever active principle of the association of ideas, we may venture to affirm that man cannot form any new term which is wholly and absolutely insignificant; but that it must have some latent analogy, some similarity or affinity either with personal feeling, caprice, or conceit. The question then is, whether it is more philosophical and scientific to adopt names called insignificant, but which are really founded on some fancy or caprice, as the ancients transferred the names of animals to certain parcels of stars; or appellations derived from some efficient inherent principle, and founded on the ablest efforts of reason at the period of their adoption. The former have flattered the vanity and excited the enthusiasm of weak minds, but never smoothed the way to any discovery or improvement; whereas the latter always awaken new associations in the mind which receives them, expand the actual basis of knowledge, and become the stepping-stones to new, and, if possible, still more important discoveries. The natural and literary history of the terms oxygen, hydrogen, oxymuriatic and muriatic acids, demonstrates the truth of this observation; and had these substances been designated by arbitrary and insignificant names, or the names of their accidental discoverers, it is mose than probable that half the experiments to which they have been subjected, in order to ascertain the propriety or impropriety of their nomenclature, would never have been performed, nor the science of chemistry be so far advanced in mathematical certainty and practical utility as we now find it. Werner's practice of mineralogical nomenclature is unquestionably the most pernioious part of his dogmatic system.-TaANs. 
Reflections on some Mineralogical Systems.

jections in the details which I have already made to two parts of his system, I shall make three other charges generally to the method of Werner. He has made all his appeals to very incompetent judges-our senses; he has stopped to describe instead of defining; and he has attempted to exclude the aid of other sciences in order to render mineralogy independent in its means.

Far from avowing that the first of these objections is really, one, the partizans of Werner consider it as a very great advantage that he appeals solely to our senses, as they are the unchangeable judges of properties which do not vary; and much stress is laid on the stability of external characters. While the other means of diagnosis and of classification change, it is said, from day to day, the external characters remain the same; and that which has served to distinguish a mineral to-day, will serve the same during a thousand years; whereas, on the contrary, not a month passes without some considerable change in chemistry*. The senses of the human species, according to all appearance, are the same that they were since the creation of man; and the properties of the mineral kingdom have no more changed than they. But from one individual to another their perfection and their delicacy constantly vary. This stability, therefore, of the means of judging external characters, is but apparent; it exists from one generation to another, but it is null between individuals. Hence the stability of external characters becomes illusory.

But, even granting to the applications of our senses more advantages than they really posses, their effect would be to retard the progress of all knowledge in which they should be employed as exclusive means, and to prevent us from ever attaining that state which is designated by the name of science. It must be remembered, that the nuarch of the latter is progressive; that each day adds something to its precision, and some principle which becomes the basis of new improvernents. Its treasures are like an inheritance which prospers in the trands of those to whom it has devolved; they offer incessantly new riches, added to those which have already been amassed during preceding cen-

* This capability of change occurs only in those arts and sciences which are susceptible of improvement with the progress of knowledge. 'To boask therefore of the uniform stability or stationariness of any science, is but to convert one of the greatest defects in any branch of human knowledge into a superlative merit. If mineralogy was henceforward to remain in the state it is now placed by Werner, it would be as useless to society, as unworthy of human study and genius, as the fancied music of the spheres was to the eacients.-TRANs. 
turies. But the faculty of appreciating qualities inmediately sensible, not requiring either profuund study or complicated reasoning, anoner attains its highest point, since the improvement of our senses by the habit of using them is the most certain way to succeed. No series of words can represent the tact which distinguishes a practitioner from a theorist; no precept can communicate it. He who has passed a long life in seeing, touching, and feeling, even when he has done every thing for himself, has no legacy to leave to posterity. In the balance, which I suppose at first to have been a simple pole suspended by the middle, imperfections were seen and attempted to be corrected; possible meliorations were perceived and executed. The instruments themselves have been the registers of these changes, and we have many of them less imperfect than those of our ancestors. Yet he who could have acquired the faculty of judging of masses near to the millionth part, would have contributed less to the instruction of after ages than the balance which would have been broken.

If the external characters are so stable as Werner tells us; and thev are so in effect; why has he so often changed the place of all minerals one after another in his system ? Is it that the colour, the specific gravity, the hardness, are not the same this year as the last? Have they not the same value; or are they not seen with the same eye? If by the extension of means, by the acquisition of new knowledge, he had prepared rational changes; if he had substituted a verity in place of an error, his system would have truly gained. But simply to change one truth for another, or put one error in the place of another, is not a progressive march in the sciences.

As to the second of these objections, it appears sufficiently proved by all which bears the name of accurate knowledge, that definitions are the language of the sciences. The mathematics rest on definitions; chemistry and physics can define much; natural history, rarely. Zoology and botany may define the generalities and describe the details. Mineralogy describes both, and defines almost nothing. Not that a descriptive method is unnatural; it is without doubt the first which men used. If we open our eyes on the grand features of Nature, the language of description is all that will remain with us, as it belongs to astonishment and admiration. It lends itself to all our sentiments, it alters not the vivacity of them, and we may almost add that to exaggerate with it is not to pervert truth. It especially suits that najestic harshness of nature which refuses our rules 
and revolts against our sciences : but whatever may be its charms, it has no principles but our sensations; and a science purely descriptive is a contradiction.

Among thousands of persons who consider the same thing, each will describe it according to his own ideas, and no one will be able to recognise it by the picture which another shall have made. But a definition is the same to all men; it is precise. If it totter, it is overthrown; whereas descriptions are satisfied with coming near. If by the one we are less exposed to commit errors, because we have established principles; by the other we are less in a condition to prove that we have been deceived, as we have followed no principle.

This is not the only inconvenience of a descriptive method. He who wishes to give a description, examines the object entire and in detail. He varies the aspect in a thousand different manners, till he believes that he has exhausted its sensible properties. If the object be one of those which are susceptible of classification, and if it is a species which we wish to describe, this species suffers itself to be divided into varieties, and these varieties are composed of individuals whose number is almost infinite. It is therefore necessary to comprehend in the description all the essential and accidental qualities of the known individuals; otherwise, it would be right to refuse a place in the species to all those which had not this quality, or which could have it from others. If the description be well done,-if it be given in detail, - we shall have a picture which will present the whole of all the scattered features in divers individuals : but if there be some property wanting in any of these individuals, this property excludes the species; for the species can have neither more nor less than what is found in the individual. To find the true specific character then, we must survey all the particulars of this picture, to discard what belongs not in common to all the individuals, for the rest is useless as a means of specification. We must search, in order not to see; and learn, expressly to forget.

Let us illustrate this by example.-In the work of Brochant we find that the first subspecies of fluor has two colours, the second three, and the third four. What then is the colour of the species? If all belong to it, we might represent fuor by the palette of the painter. If it has only one, why not name it without mentioning others? If none properly belongs to it, why cite the colour as a specific character?

Vol, 37. No. 153, Jan. 1811 .

$\mathbf{D}$ 
If we view mineralogy only with respect to its application to the useful arts, and particularly to that of the miner, we might limit our knowledge to the simple diagnosis of minerals, and the most prompt and easy means would be the best; but if we conceive it capable of being placed in the highest rank, we stall never attain this object but by the assistance of knowledge derived from analogous sciences. It is by having long confounded specification with diagnosis, the philosopher with the miner, that we have not distinctly followed the different objects that have been proposed, and that we have not estimated the means employed according to their just value. It must indeed be confessed that the superiority of Haüy's system over that of Werner is infinitely greater in that part which relates to the establishment of species, or the philosophy of the science, than in the art of knowing minerals. We cannot expect that the mincr, in exploring the earth, should select the specimens which he meets, distinguish them by their geometric figures, or seek every direction of the cleavage for the integral molecule. He must have more simple and more expeditions means : without a great effort of mind he must be able to avoid error; and provided that he does not greatly deceive himself respecting the contents of the metal which he explores, he is allowed to be not very rigorous as to the species of the individual. The jeweller may make as many species as colours; the weak virtuoso may dispute on the prism of emerald, jasper, oriental and occidental stones, \&c.; but the naturalist should decide rather with certainty than celerity : he neither wishes to deceive himself nor diffuse a false light on science. He can return to the same ubject every time he pleases, can revise or correct his ideas, remould his opinions, diversify their sources, compare them, discuss them, and leave his doubts an inheritance to science; for his discoveries, and the moments which he bas employed in hesitation, are precious to truth; while that time, with the artist, is an element of expense, and promptitude indemnifies him for less perfection. With justice might the latter blame the length and difficulty of the researches necessary to acquire the indispensable certainty that a mineral belongs to such or such a species, according to the principles of Haüy. But when I have heard this objection made by a man of learning, who professes mineralogy as a science, I have not been able to conceal my astonishment. "How would you do, (said he to me, when one must pronounce on some hundreds of minerals in an hour or two?" To the botanist, 
botanist, all the time necessary to his inquiries is allowed: the zoologist may consult anatomy and physiology at his leisure; he can observe the habits of animals : the gardener must not wait the time of inflorescence to distinguish plants : the butcher should know an ox or an ewe without being obliged to ascertain if they could reproduce beings fecund and similar to themselves : in like manner the miner ought not to stop at particulars : but I do not see why, among all those who studly nature, the mineralogist should be the only one condemned to live in a perpetual hurry.

['To be continued.]

VIII. On Cystic Oxide, a new Species of Urinary Calculus. By William Hyde Wollaston, M.D. Sec.R.S.*

$\mathrm{T}$

HE principal design of the present essay is to make known the existence, and to describe the leading properties, of a new species of urinary calculus from the human bladder; but I shall at the same time take the opportunity of correcting an inaccuracy or two that I have observed in my former communication on this subject. (Phil. Trans. 1797.)

I on that occasion took notice of five kinds of urinary calculi,

1. The lithic acid, since called uric acid, originally analysed by Scheele.

2. The oxalaie of lime, or mulberry calculus.

3. The phosphate of lime, or bone-earth calculus.

4. The ammoniacal phosphate of magnesia.

5. The fusible calculus, which consists of the two last species combined.

It is now about five years since I first met with another species, evidently differing from each of those before described. It was in the possession of Dr. Reeve of Norwich, who obligingly gave me a portion of it for the purpose of examining its chemical qualities. It had been taken from his brother when he was five years old, and at that time was covered with a coating of phosphate of lime very loose in its texture, and consequently very soon separated $\dagger$. This species is probably very rare; for, although I have omitted

* From Philosophical Transactions for 1810, Part II.

+ I am informed, that another stone formed afterwards in the bladder of this boy, and that he died in consequence, without submiting to the operation a second time. The stone found in his bladder after dęath, consisted principally of uric acid, but was peculiar in one respect, as its centre was hollow by the removal of some nore soluble substance, of which the nucleus had consisted.

$\mathrm{D} 2$ 